\title{
NOTES
}

\section{SOLICITATION OF ASSENTS TO RAILROAD REORGANIZATION PLANS UNDER SECTION 20b OF THE INTERSTATE COMMERCE ACT}

Section 20b of the Interstate Commerce Act, enacted in $1948,{ }^{1}$ is Congress' most recent attempt to provide a fair and efficient procedure for the reorganization of railroad carriers. ${ }^{2}$ If the statute's substantive criteria are met, $^{3}$ the Interstate Commerce Commission may allow carriers to modify all of their securities, except equipment trust certificates. ${ }^{4}$ Court approval is unnecessary ${ }^{5}$ to make a modification binding on all parties $;^{6}$ constummation

1. 62 Stat. 163 (1948), 49 U.S.C. $\$ 20 \mathrm{~b}$ (Supp. 1951). The legislation is often cited as the "Mahaffie Act," after Charles D. Mahaffie, former chairman of the Interstate Commerce Commission, its reputed author. For general surveys of the background and sub. stantive aspects of the statute, see Hand \& Cummings, Consenstal Scctritics Modification, 63 Harv. L. Rev. 957 (1950); The Railroad Modification Law, 48 CoL. L. KEv. 68! (1948); Oliver, The Railroad Readjustment Act, 15 I.C.C. PrAc. J. 527 (1948) ; Polatsek, The Wreck of the Old 77, 34 CoRN. L. Q. 532 (1949); Comment, 58 Y YL.E L.J. 1291 (1949) ; Note, 1 Stan. L. Rev. 676 (1949).

2. The now defunct Chapter XV of the Bankruptcy Act, 53 Srst. 1134 (1939), 56 STAT. 787 (1942), was an earlier, but short-lived, attempt at consenstual securities modification. See Will, Chapter XV of the Bankruptcy Act-An American Adaptalion of the Fait Accompli, 7 U. of Chi. L. Rev. 203 (1940). Section 20b was itself preceded by several other bills, one of which was vetoed by President Harry S. Truman. Sce Menio* randum of Disapproval, Hearings before Subcommittec of the Committec on Interstate and Foreign Commterce on S. 249, 80th Cong., 1st Sess. 12 (1947).

3. The ICC must find the submitted plan to be "in the public interest; $\ldots$ in the best interests of the carrier, of each class of its stockholders, and of the holders of each class of its obligations affected" by the plan, and not "adverse to the interests of any creditor of the carrier not affected" by the proposed modification. 62 STAT. 163 (1948), 49 U.S.C. $\$ 20 \mathrm{~b}(2)$ (Supp. 1951). For an analysis of ICC interpretation of 20b standards, see Wren, Feasibility and Fairness in Section 20b Reorganizations, 52 CoL. L. Rev. 715 (1952) ; Fand \& Cummings, Funding Arrearages under Section 20 of the Interstatc Commerce Act, 65 HARv. L. Rev. 398 (1952); Comment, 61 YALE L.J. 656, 676-82 (1952).

4. Section $20 \mathrm{~b}(1)$.

5. Unlike the traditional statutory provision for constant, and $d e$ novo, court participation in bankruptcy reorganization proceedings, c.g., 47 STAT. 1474 (1933), as amended, 11 U.S.C. $\$ 205$ (1946), 20b contains no mention whatever of judicial review. Challenge of an approved $20 \mathrm{~b}$ plan can thus be made only by way of a limited administrative revicw under 28 U.S.C. $\$ \S 1336,2101$ (a), 2284, 2321-25 (Supp. 1950), in which courts will bo confined to a determination of whether ICC holdings were supported by any "rational" evidence. See Mississippi Valley Barge Line Co. v. United States, 292 U.S. 282, 286 (1934) ; Interstate Commerce Commission v. Union Pacific R.R., 222 U.S. 541, 547-8 (1912).

6. Dissenters from a $20 \mathrm{~b}$ plan have no right to demand cash payment from the corporation for their securities. Contrast the appraisal statutes which, in forty-three juris- 
of a submitted plan is contingent solely on ICC sanction and the assentsexcluding those within the control of the carrier or any person controlling the carrier ${ }^{7} \longrightarrow$ of at least 75 percent of the shares or principal amount outstanding of each class of affected securities. ${ }^{3}$ Clearly, the absence of judicial supervision poses no threat to the interests of management, which retains the initiative to file or withdraw $20 \mathrm{~b}$ applications, ${ }^{9}$ or to institutional investors, whose relatively large holdings may grant them a veto power over any plan which they believe affects them adversely." But the small investor, without the money or skill to protect his interest, ${ }^{11}$ must depend on the astuteness of the Commission and the reliability of the assent solicitation process to bluel: over-reaching by management or other dominant groups. ${ }^{12}$ Aside from ICC supervision, the required percentage of assents, unusually high for a reorganization procedure, ${ }^{13}$ appears on its face to be an imposing shield for the small

dictions, ease the burden of various forms of consensual securities mudification by requiring such purchase. Jote, 60 Yale L.J. 337 n.1 (1951). Sce, generally, Ealla:inne, Coaporations $\$ \$ 298,299$ (rev. ed. 1946) : Stevens, Cosfobations $\$ 123$ (2d cd. 1949). For a recent critique of appraisal statutes, see Nute, 38 VA. L. KEv. 915 (1952).

7. Section $20 \mathrm{~b}(3)$.

8. Section $20 \mathrm{~b}(2)$. However, if fewer than 25 persons hold 75 percent ur mure of outstanding securities in an affected class, the ICC may require a percentage of assents higher than the usual 75. Ibid. See Boston \& Miaine R.R. Securities Mfudification, 275 I.C.C. $397,421-2$ (1950) ( 87 percent required for noncumulative preferred stoels).

9. Section $20 \mathrm{~b}(2)$. Several $20 \mathrm{~b}$ applications have been withdrawn. See 65 ICC Aara. REP. 34 (1951) ; 63 ICC ANN. Rep. 26 (1949); 62 ICC ANs. Kep. 31 (1945).

10. Thus the Reconstruction Finance Corporation, owner of all outstanding cullatcral trust 4-percent bonds of the Bangor \& Aroostouk R.R., cuuld easily have blosked any uncongenial 20b plan. See Bangor \& Aroostuok R.R. Securities Modifieation, 275 I.C.C. 369,370 (1950). One writer has estimated that at least half of all outstanding railruad bonds are owned by insurance companies and banks. Hodghino, Consoratio: Franate 655 (3d ed. 1947).

11. "Courts of Equity have a tradition of aiding the helpless, such as Iniants, Idiuts, and Drunkards. The average security holder in a corporate reurganization is of life kind." Frank, Some Realistic Reflections on Some Aspects of Curparate kcorgantisation, 19 VA. L. REv. 541, 569 (1933). See last paragraph of note 44 infra.

12. See Missouri-Kansas-Texas R.R. Securities Modification, 275 I.C.C. 499 (1950) (application denied) ; Mraine Central R.R. Securities Modification, 275 I.C.C. 261 (1950) (same). The MI-K-T has filed a new $20 \mathrm{~b}$ application, an avowed purpose of which is to maintain the present management's control of the road. N. Y. Times, Jan. 1, 1953, g. 32, col. 2.

Carriers need not justify even the most drastic $20 \mathrm{~b}$ plan with proof of present or impending insolvency. See, e.g., Boston \& Maine R.R. Securities Irodification, 275 I.C.C. 397,412 (1950). Nor, probably, need plans adhere to the standard of "iull priority" in securities allocation to senior security interests. Hand \& Cummings, Furddisg Arrcaraygs Under Section $20 \mathrm{~b}$ of the Interstate Commeres Ait, $65 \mathrm{Hanv}$. L. Rev. 393 (1952); Consensual Securities Modification, 63 HARv. L. Rev. 957, $981-84$ (1950); Comment, 61 Yale L.J. 656 (1952). Compare these views with Wren, Facsilility and Fairicss in Sction $20 b$ Reorganizations, 52 CoL. L. KEv. 715 (1952).

13. Both state and federal corporate reorganization procedures custumarily provils: for the ratification of any reorganization plan by given percentages of a company's securi- 
investor's protection; its efficacy, however, depends on the practices by which assents may be obtained.

Section 20b itself offers few guides to aid the ICC in the formulation of rules for assent solicitation. The statute provides that "all letters, circulars, advertisements, and other communications" to be used in soliciting, or opposing, assents must first be submitted to the ICC for approval of the "correctness and sufficiency" of the material facts contained therein. ${ }^{14} \mathrm{Be}$ yond this, the ICC is left free to devise its own rules and regulations regarding the submission of $20 \mathrm{~b}$ plans to security holders. ${ }^{15}$ Emphasizing this broad discretion is a specific provision which makes the Security and Exchange Commission's proxy rules inapplicable to $20 \mathrm{~b}$ proceedings. ${ }^{10}$ The ICC, in passing on ten $20 \mathrm{~b}$ plans during the past five years, ${ }^{17}$ has evolved a series of general solicitation rules. Carriers are permitted to employ professional solicitors who may use personal contact to obtain assents. ${ }^{18}$ Normally the Commission will not, nor are opponents allowed to, inspect the accuracy of the

ty holders-but none imposes as high an assent requirement as that found in $20 \mathrm{~b}$. Compare 20b's provision (75 percent of each class of affected securities) with the assent requirement for reorganizations under Section 77 of the Bankruptcy Act, 47 SrAr. 1474 (1933), as amended, 11 U.S.C. $\$ 205$ (e) (1946) (two-thirds of those voting), or under Chapter XI readjustments, 52 STAT. 905 (1938), 11 U.S.C. $\$ 762$ (1946) (simple majority of all creditors), or under state charter amendment procedures, c.g., DEl. Rev. ConE, c. $65, \S 26$ (1935) (majority of stock eligible to vote) ; N.J. REv. STAr. \$14.11-2 (1937) (two-thirds) ; N.Y. STock CoRP. LAw Art. IV, $\$ 37$ (a) (b) (c) (majority or two-thirds).

14. Section $20 \mathrm{~b}(2)$.

15. The Commission is given the power: "to make such rules and regulations appropriate to its administration of the provisions of [Section 20b] as it shall deem necessary or desirable," 62 STat. 163 (1948), 49 U.S.C. $\$ 20 \mathrm{~b}(10)$ (Supp. 1951) ; to attach to any" plan "such terms, conditions, and amendments, if any, as the Commission shall have determined to be just and reasonable," 62 Stat. 163 (1948), 49 U.S.C. § 20b(3) (Supp. 1951); "to cause the carrier, in such manner as it [the ICC] shall direct, to submit the pro. posed alteration or modification" to security holders. 62 STAT. 163 (1948), 49 U.S.C. $\S 20 \mathrm{~b}(2)$ (Supp. 1951).

16. Section $20 \mathrm{~b}(9)$.

17. Macon, Dublin \& Savannah R.R. Bond Modification, 271 1.C.C. 376 (1948); Central R.R. of N.J. Securities Modification, 271 I.C.C. 501 (1949) ; Lehigh Valley R.R. Securities Modification, 271 I.C.C. 553 (1949); Southern Ry. Abandonment (Atlantic \& Danville Ry. Securities Modification), 271 I.C.C. 605 (1949); Montana, Wyoming \& Southern R.R. Securities Modification, 271 I.C.C. 779 (1949); Maine Central R.R. Securities Modification, 275 I.C.C. 261 (1950); Bangor \& Aroostook R.R. Securities Modification, 275 I.C.C. 369 (1950) ; Boston \& Maine R.R. Securities Modification, 275 I.C.C. 397 (1950) ; Missouri-Kansas-Texas R.R. Securities Modification, 275 I.C.C. 499 (1950); Maryland \& Pennsylvania R.R. Securities Modification, 275 I.C.C. 695 (1950). All but the Maine Central and the M-K-T plans won Commission approval.

18. "[T]he applicant may retain the services of one or more firms specializing in such work to assist in solicitation; . . . reasonable provision may be made for the cont'pensation of brokers in connection with the solicitation of assents; and ... such solicitation may be carried on by personal interview, mail, telephone, and telegraph. . . ." Central R.R. of N.J. Securities Modification, 271 I.C.C. 501, 529 (1949). See notes 32-58 illfra, and accompanying text. 
recordation of assents. ${ }^{19}$ To aid in opposing $20 \mathrm{~b}$ plans, dissenters may either obtain the names of other security holders from the carrier, or, if the carrier refuses to disclose its lists, pay the carrier to mail opposition literature.20 In no case, however, will dissenters receive reimbursement from the carrier for campaign expenses. ${ }^{21}$

The first court test of a $20 \mathrm{~b}$ plan 22 provides a framework for a critical examination of the Commission's rules. In Sakis $\%$. United States, ${ }^{23}$ disgruntled preferred shareholders of the Boston \& Maine Railroad sought to invalidate a plan which the ICC and the requisite number of security holders had approved. ${ }^{24}$ Part of the plaintiffs' attack was aimed at the ICC's solicitation rulings. ${ }^{25}$ The challenge was aided by an unexpected Justice Department

19. "To grant the intervener's request that they be given an opportunity to make an individual investigation and inspection [of the recording process] such as they suggest obviously would result in substantial further delay. In the complete absence of any evidence, or even any allegation ... that any errors or irregularities occurred in the certifying of the results of the submission, we must conclude that there is no justification for thus delaying the consummation of this proceeding. . . . [W]e accept the depositary's certification at its face value." Boston \& Maine R.R. Securities Mudifieation, 275 I.C.C. 752, 755-6 (1951). See notes 59-73 infra, and accompanying text.

20. "[T] he applicant shall supply to any holder of an affected security ... . a reasonably current list of the names and addresses of the holders . . . of the securities of the same class as those of the holder making the request: or, as alternatives to suplying stch list, ... may, if if so elects, mail, at the expense of such holder, copies of any material, the correctness and sufficiency of which have been approved by us, proposed to be used by such holder in connection with the solicitation of assents or dissents to the plan of alteration and modification." Bangor \& Aroostook R.R. Securities Mradification, 275 I.C.C. 369, 395 (1950) (emphasis added). See note 47 infra.

21. "Under section $20 \mathrm{~b}$ of the Interstate Commerce Act no provision is made for us to authorize or direct payment by the applicant of compensation or reimbursement of expenses of parties to the proceedings. ... [T] he petition [for reimbursement] will be denied" Lehigh Valley R.R. Securities Modification, 271 I.C.C. 655, 658 (1949). See notes 74-9 infra. and accompanying text.

22. An earlier challenge of $20 \mathrm{~b}$, which sought to invalidate the seeurities readjustment granted in Macon, Dublin \& Savannah R.R. Bond Modification, 271 I.C.C. 376 (1948), was dismissed on technical grounds. Holmes v. United States, 89 F. Supp. $\$ 94$ (S.D.N.Y. 1949), aff'd, 339 U.S. 927 (1950) (failure to exhaust administrative remedies). A projected appeal from ICC approval of the Lehigh Valley reorganization in Lehigh Valley R.R. Securities Modification, 271 I.C.C. 553 (1940), was withdrawn on motion of the parties. 65 ICC ANN. REP. 160 (1951).

23. 103 F. Supp. 292 (D.D.C. 1952), dismissed by consent of farties, 344 U.S. 801 (1952).

24. Boston \& Maine R.R. Securities Modification, 275 I.C.C. 752 (1951). To simplify the road's complex capital structure, the plan required investors in the four outstanding stock classes to surrender their securities for certain percentages of two new stod: issues.

25. Also challenged were ICC findings on classification of Boston \& Maine stocl: rate of capitalization, and adherence of the plan to substantive $20 \mathrm{~b}$ standards. In addition, plaintiffs claimed that $20 \mathrm{~b}$ was unconstitutional as a violation of the Due Process Clause of the Fifth Amendment and as an unlawful delegation of legislative powers. All contentions were denied. Sakis v. United States, 103 F. Supp. 292 (D.D.C. 19\$2) fassin. 
investigation which produced numerous affidavits and depositions alleging irregularities in the solicitation of assents to the plan. ${ }^{26} \mathrm{~A}$ three-judge district court 27 ignored this evidence because of the untimely nature of its presentax tion $^{28}$ and upheld the general rulings of the ICC. While plaintiffs appenled to the Supreme Court ${ }^{20}$ the ICC undertook a review of the alleged irregularities. $^{30}$ The Court later dismissed the appeal on the parties' own motion, ${ }^{01}$ and the Commission has yet to render an opinion on the alleged irregularities. Whether fact or fantasy, however, these allegations reveal the practices made possible by the ICC rules and, coupled with financial obstacles to effective minority opposition, suggest that the requirement of security holder approval may be an illusory safeguard against unfair $20 \mathrm{~b}$ plans.

\section{Oral Solicitation}

Plaintiffs in the Sakis case argued that Congress had forbidden oral solicitation in $20 \mathrm{~b}$ campaigns via its statutory requirement that all letters, circulars,

26. In its position as statutory defendant of any action brought to restrain cnforcement of an Interstate Commerce Commission order (62 Star. 970 (1948), 28 U.S.C. $\$ 2323$ (Supp. 1950)), the Justice Department originally filed a pro forma answer to the Sakis suit, generally upholding the Commission's stand. For reasons that are not apparent. the Department then embarked on a surprisingly intense investigation of solicitation and recording activities in the Boston \& Maine reorganization, and employed antitrust and FBI offices throughout the country to take affidavits. (Questioning of railroad and depositary officials may have been facilitated by a mistaken notion on their part that the Government was seeking evidence in support of the Boston \& Maine plan.) Shortly before the court hearing, the Justice Department amended its answer to "confess error" on the issue as to whether the proper number of assents had been legally attained, but continued to support the Cominission in upholding the constitutionality of $20 \mathrm{~b}$. Counsel for the Boston \& Maine and the Old Colony Trust Company (the road's depositary) strentiously fought the Government's attempt both to confess error and to present its evidence to the court. See, e.g., Motions on Behalf of Boston \& Maine R.R. passim, Memorandum on Behalf of Intervenor Old Colony Trust Company in Support of its Motion to Strike passim, Sakis v. United States, 103 F. Supp. 292 (D.D.C. 1952). For a brief discussion of the legal and factual issues concerned in "confession of error" situations, see Stern, " $I n$. consistency" in Govermment Litigation, 64 HARv. L. REv. 759 (1951).

27. The Judicial Code provides for three-judge determination of any action in which either an interlocutory or permanent injunction is sought to restrain the enforcement of an! Interstate Commerce Commission order "other than for the payment of money or the collection of fines, penalties and forfeitures." 62 STAT. 970 (1948), 28 U.S.C. §2321 (Supp. 1950).

28. The Justice Department investigation commenced after the ICC had terminated its proceedings, see note 26 supra, and Government affidavits were presented for the first time in court hearings. Since the court deemed its function to be that of merely reviewing an administrative record, it refused to consider the Justice Department allegations as original evidence. Sakis v. United States, 103 F. Supp. 292, 313-14 (D.D.C. 1952).

29. 21 U.S.L. WEEK 3048 (U.S. Aug. 12, 1952).

30. 66 ICC ANN. REP. 40 (1952).

31. Sakis v. United States, 344 U.S. 801 (1952). ICC records indicate that the plaintiffs received a cash settlement from the Boston \& Maine. 66 ICC ANN. REP. 40-1 (1952). 
advertisements and "other communications" receive Commission approval before transmission to security owners. Since oral communications obviously cannot be so approved, plaintiffs contended they were excluded from $20 \mathrm{~b}$ use. $^{32}$ The Sakis court denied this claim by interpreting "other communications" to mean only written matter, and revealed the motive for its decision in a pointed discussion of the difficulty of management's task in obtaining the required high percentage of assents without the use of personal solicitation. ${ }^{33}$ The court recognized that abuses might accompany oral persuasion, but found assurance of safety in the fact that solicited owners could check the validity of any oral allegation by referring to approved written statements. ${ }^{34}$

Though the Sakis court was quite correct in finding no specific statutory prohibition of oral solicitation-Congress, in fact, never considered the matter ${ }^{35}$-there is good reason to justify judicial interpolation of such a ban. The only assurance of a full and fair presentation of $20 \mathrm{~b}$ plans to security holders lies in the provision for a prior ICC check over both the "correctness and sufficiency" of solicitation communications. ${ }^{30}$ No criminal sanctions exist to

32. Brief for Plaintiffs, pp. 20-1, Sakis v. United States, 103 F. Supp. 292 (D.D.C. 1952).

33. Sakis v. United States, 103 F. Supp. 292, 305 (D.D.C. 1952).

34. Ibid. Section $20 \mathrm{~b}$ itself does not oblige carriers to submit written communications to security holders, but it seems likely that the ICC will require this in every case.

35. As far as can be determined, discussion of ICC supervision of campaign communications accurred only once in years of committee hearings and flcor debates on $20 \mathrm{~b}$ and its predecessor proposals. On that occasion, managers of the MFahaffie bill told the Senate that it was not their intent to establish Commission censorship over "normal or ordinary correspondence between a carrier and a stoclholder." 94 Cosic. REc. 3271 (1948). This statement sheds little light on congressional attitudes toward mass oral solicitation.

36. A legislative policy against oral solicitation may be inferred from this requirement. Compare the provision for a prior ICC check over both the "correctness and suffciency" of campaign communications with the regulations governing Section 77 solicitation efforts in 49 CODE FED. REGs. $\$ 5 \$ .1-12$ (1949), which require no prior ICC appruval of solicitation arguments, although the statute does require that copies of the reorganization plan and the court's order be mailed to creditors and shareholders. 47 STAT. 1474 (1933), 11 U.S.C. $\$ 205$ (e) (1946). Nor must solicitation arguments in Chapter X reorganizations be submitted for prior agency censorship. although no solicitation may begin until creditors and shareholders receive copies of the plan and the court opinion appruving the plan. 52 STAT. $\$ 91$ (1938), 11 U.S.C. \$\$575-6 (1946). MLoreover, the supervisiun provided in Schedule 14A and Rule X-14.A-9 of the well-known SEC rules for proxy regulation, 17 CODE FED. REGs. S\$ 240.14a-1 et seq. (193S), applied to solicitations under \$14(a) of the Securities Exchange Act of 1934, 4 Sr.AT. $\$ 95$ (1934), 15 U.S.C. \$7\&n(a) (Supp. 1951), $\$ 12(\mathrm{e})$ of the Public Utility Holding Company Act of 1935, 49 SrAr. $\$ 24$ (1935), 15 U.S.C. $\$ 79(\mathrm{k})$ (Supp. 1951), and $\$ 20(\mathrm{a})$ of the Investment Company Aet of 1940 , 54 SтAт. $\$ 22(1940), 15$ U.S.C. $\$ \$ 0 \mathrm{a}-20$ (Supp. 1951), requires only that the company disclose certain minimal facts and refrain from using "false and misleading" statements. The seemingly stronger statutory safeguard in $20 \mathrm{~b}$ may indieate that Congress intended that only the most closely supervised communications-which oral persuasion could never be-should reach security holders. 
deter the use of false and misleading arguments. ${ }^{37}$ Yet oral solicitation, so conducive to misleading argument and innuendo, can nullify the sole check Congress imposed. Solicitors, particularly when paid on a sliding scale correlated to the number of assents they acquire, ${ }^{38}$ can be expected to exercise every possible wile of oral persuasion. ${ }^{39}$ This expectancy is borne out by the Justice Department investigation of the Boston \& Maine campaign which revealed startling instances of oral misrepresentation of the value of Boston \& Maine stock ${ }^{40}$ and the carrier's financial position. ${ }^{41}$ In addition, solicitors allegedly offered fantastic inducements to obtain assents: one promised a job with the Boston \& Maine and a loan to the son of a security holder ; ${ }^{42}$ on another occasion both a position on the board of directors and lowered ship-

37. The wording of $\S 20 \mathrm{~b}(9)$ which rendered the SEC's proxy rules inapplicable to $20 \mathrm{~b}$ proceedings also prevents the application of the criminal sanctions of the Securities Exchange Act to $20 \mathrm{~b}$ campaign tactics. Nothing in $\$ 20 \mathrm{~b}$ 's legislative history indicates that this was the intended result. Compare the stringent criminal penalties guarding railroad reorganizations under Section 77 of the Bankruptcy Act. 47 SrsT. 1474 (1933), as amended, 11 U.S.C. $\$ 205$ (p) (1946).

38. The ICC has approved the practice of compensating the solicitor according to the number of assents he acquires. See, e.g., Bangor \& Aroostook R.R. Securities Modification, 275 I.C.C. 369,378 n.2 (1950).

39. For a suggestion of the other motives that may impel an extraordinary effort by paid solicitors to bring about the success of $20 \mathrm{~b}$ plans, see Letter of B\&M-11 (a paid solicitor for the Boston \& Maine), dated November 8, 1950, Exhibit 2, Deposition of B\&:M-11, p. 14, October 17, 1951, photostatic copy on file in Yale Law Library: "You will see from careful reading of my report that ... a large block of new [B\&M] $\$ 5$. pfd. and new [B\&M] common [will soon be] for sale. I am to have first chance at it."

40. Solicitors gave common stockholders throughout the nation varying estimates of the value of Boston \& Maine shares. E.g., Affidavits of B\&M sharcholders, photostatic copies of which are on file in the Yale Law Library: B\&M-1, dated November 28, 1951 (75 cents a share) ; B\&M-2, dated November 28, 1951 (25 cents a share); B\&M-3, dated October 2, 1951 (12 cents a share); B\&M-4, dated December 2, 1951 ("under water") ; B\&M-5, dated November 28, 1951 ("practically worthless"). In the late months of 1950 when these representations were made, Boston \& Maine common stock sold on the New York Stock Exchange at prices ranging from $21 / 2$ to $37 / 8$ dollars per share. See, e.g., N.Y. Times, Oct. 14, 1950, p. 23, col. 2; Dec. 2, 1950, p. 19, col. 3.

41. "The man who called me, in urging me to assent, stated in effect that it would be better to reorganize the railroad than to have it go into bankruptcy proccedings." Affidavit of B\&M-6, common shareholder, dated November 27, 1951, photostatic copy on file in Yale Law Library. Compare the conclusions of the ICC: "It is conceded by the applicant, and not disputed by any of the interveners, that the need for readjustment of its capital stock structure is not forced on it by reason of any threat of insolvency. On the contrary, it clearly appears that the applicant is in good physical condition, and the evidence justifies the conclusion, generally accepted by the parties, that the applicant's funded debt structure, while perhaps susceptible to further improvement, is sound." Boston \& Maine R.R. Securities Modification, 275 I.C.C. 397,412 (1950). 'Thus, statements which never would have received ICC approval for insertion in written $20 \mathrm{~b}$ communications, reach solicited owners with ease via the back door of personal visit.

42. Affidavit of B\&M-2, dated November 28, 1951, photostatic copy on file in Yale Law Library. 
ping rates were the implied consideration for the shareholder's assent. ${ }^{43}$ And some stockholders were exposed to unremitting solicitor badgering." Moreover, even with criminal sanctions, the SEC has experienced frequent abuse

43. "Q. Did the discussions between you and [the solicitor] at any time revolve around the directors of the railroad? $A$. Oh, yes ... he saw he cuuldn't get anywhere with me and he said there were two vacancies in the Buston \& Maine Railroad directorship, and he said he believed he can get me one on the buard. $Q$. On the buard oi direetors? A. Yes, and also if $I$ was shipping any stuff, merchandise, through the Bustun $S$ : Maine Railroad he would get me a cheaper rate. . . . Now, did there coms a time when [he] discussed with you the question of whether or not you might go to Bunt.n, Massachusetts, for any reason? A. Oh. yes, he wanted to show me the workings of the railroad and he said, "Any time you want to make arrangements it is up to you. lius can stay with your wife two or three days in Boston. We will put you up in a hitel and entertain you and try to make it very convenient for you.' He did try to malse it very convenient for me, and he also sent ... [my wife] flowers. Q. Now, with respeet to the proposed trip to Boston, who was to pay the expenses? A. The Boston \& Maine Railroad." Deposition of B\&Ar-7, pp. 8-9, dated November \&, 1951, photestatic cupy on file in Yale Law Library. Deponent actually made the trip to Euston, where he was met by three officers of the Boston \& Maine Railroad. Id. at 11-14. "Q. Incidentally, who yaid for the drinks? A. I think the Boston \& Maine Railread did that." Id. at 17. "Q. Why paid your bill at the Manger Hotel [in Eoston], your hotel bill for the room? A. I don't know. I don't think I paid for it." Id. at 20.

44. "He [the solicitor] came about four times when I actually let him in and ten or twelve times when I refused to let him in." Affidavit of BS:M-2, dated November $2 \mathbb{B}_{\text {. }}$ 1951, photostatic copy on file in Yale Law Lihrary. Other shareholders were phoned or visited, c.g., at least nine times, Affidavit of B\&.دI-3, dated October 2, 1951; "ssveral times," Affidavit of BSM-8, dated September 5, 1951, photostatic copies un file in Yale Law Library. "[We] don't think it [solicitation] can be done by phone but will require personal calls, perhaps several times. . ." Letter from Georgeson \& Co. 1 a sulicitation firm) to the Boston \& Maine R.R, dated October 9, 1950, Exhibit 1, Derrssitica of Richard Nye, photostatic copy on file in Yale Law Library.

Other solicitor tactics: "He ... told me that the necessary percentage of stodholders was assenting to the reorganization plan anyway, but that as of the day he was talling t.s me the railroad still lacked the assent of a few of the stockholders, and he wuuld therefore appreciate my signing the letter of assent and returning it immediately.... He then said that my failure to sign the assent was holding up the reorganization plan, and that. since enough of the stockholders were going to assent anyway, the souner the railread got the necessary percentage of stockholders to assent, the sconer the re-organization wauld be effected for the benefit of both the railroad and all the shareholders." Affidavit af B\&N1-9, dated November 27, 1951, photostatic copy on file in Yale Law Library. At approximately the same time, a partner in one of the road's chicf solicitation firms wruts the road: "Frankly, I just don't know how you're going to get the necescary assents." Exhibit 1, attached to Deposition of Richard Nye, photostatic copy on file in Yale Law Library. Another shareholder was told that Mr. George Salis (principal oppanent of the Boston \& Maine's plan) had assented to the $20 \mathrm{~b}$ modification. "When I heard that," testified the shareholder, "I signed right away." Deposition of B\&.MI $-10, \mathrm{P} . \$ 7$, dated November \&, 1951, photostatic copy on file in Yale Law Library.

Wealthy, well-informed investors were apparently immune to these arguments. Sets Letter from Georgeson \& Co. (a solicitation firm) to the Bostun \& Maine Railruad, dated October 9, 1951, Exhibit 1, Deposition of Richard Nye, photostatic cups ca file in Yale Law Library: "So far we have only solicited brokers plus twò or three larger 
of oral solicitation in proxy battles. ${ }^{45}$ Furthermore, the Sakis court's reliance upon the accuracy check afforded by written communications is of dubious wisdom in view of common psychological evidence of the superior persuasiveness of oral argument. ${ }^{46}$

Ideally, oral solicitation should be forbidden. ${ }^{47}$ Short of this, Congress or the Commission should erect strong safeguards against abuse. A prohibition of solicitor contracts which make compensation contingent upon success in obtaining assents might minimize inducements for misleading statements ; oral solicitation might await prior receipt by the security holder of the written statements of all factions; personal visits could be limited to one appearance in place of repeated solicitor pressuring. If money and manpower are available, ICC spot checks on oral solicitation practices also should accompany each $20 \mathrm{~b}$ campaign. And Congress could contribute criminal and civil liability for the oral use of false and misleading statements to supplement inadequate state actions for deceit. ${ }^{48}$

stockholders where [we] had an entree. ... [Those] we have contacted have only one come-back-they ask satirically for the reasons they should go along as to a plan that will make their stock worth 50 cents when they can sell it in the market for $\$ 2.50$. . . As [we] see it, our best prospects are among the smaller stockholders scattered throughout the country." See note 11 supra.

45. See, e.g., the account of the struggle for control of the Sparks-Withington Company in Emerson \& Latcham, Further Insight into More Effectize Stockholder Participation: The Sparks-Withington Proxy Contest, 60 YALE L.J. 429 (1951), where management solicitors allegedly offered free Sparton television sets for shareholder proxies, $l d$. at $449-50$.

46. See Klapper, The Effects of Mass Media pt. 2, p. 10 (1949) ; Lazaksfedu, Berelson \& Gaudet, The People's Choice 129, 150-1 (1948); Wilke, An Expcrimtental Comparison of the Speech, the Radio, and the Printed Page as Propaganda Devices in Archives of Psychology No. 169 (1934).

47. Oral solicitation by management seems especially unfair because of the practical inability of any group other than management to make use of it. Refusal by the ICC to compel corporate reimbursement of the expenses of opposition groups, see note 21 supra, renders prohibitive any effort orally to persuade widespread dissent to a proposed modification. More importantly, the ICC has apparently reversed an earlier policy of requiring carrier disclosure of security holder names to opposition committees, Macon, Dublin \& Savannah R.R. Bond Modification, 271 I.C.C. 376, 384 (1948), and now permits the railroad an alternative of mailing dissent literature, at dissenters' expense, in place of actually furnishing security holder lists. See note 20 supra. Opposition groups, consequently, might be forced to use cumbersome state proceedings in order to seek the names and addresses of stockholders for purposes of oral solicitation. See BAllantine, CokrondTIONS $\$ \S 159-67$ (1946). And no state-recognized right to obtain the names and locations of bondholders exists. The inability to obtain lists of investors from management has been labeled one of the historical abuses of reorganization proceedings. Delatour $v$. Merideth, 144 F.2d 594, 596 (2d Cir. 1944). See SEC, Report on the Study and Investigation of the Work, Activities, Personnel and Functions of Protective and ReorganizaTION COMMITTEes pt. 1, 408-57 (1937).

48. Since no criminal sanctions are presently contained in $20 \mathrm{~b}$, see note 37 supra, usc of the most blatantly false and misleading oral allegations is limited only by common-law actions for deceit, the shortcomings of which were sharply highlighted in Shulman, Cizil Liability and the Securities Act, 45 YALE L.J. 227 (1933). 


\section{The "Purchase" of Assents}

Misleading oral enticements may prove to be among the less ertreme abuses of the solicitation process; pressure on solicitors to obtain the requisite assents seems to have induced a dubious manipulation of stock market trading practices as well. The Justice Department investigation of the Boston \& Maine campaign reveals that paid solicitors occasionally offered above-market prices for the stocks of non-assenters on condition that the holders assent their securities before the sale. ${ }^{49}$ After purchase, the securities were apparently resold at a loss, ${ }^{\text {;n }}$ with only the negligible risk that a later purchaser would talsu the trouble to revoke the assent before the end of the solicitation period. Ind it seems reasonable to infer that losses suffered in these transactions were later included in solicitation "expenses" paid from corporate funds. The same technique may have been used to bypass in spirit, but perhaps not in form, $20 \mathrm{~b}$ 's prohibition against counting into the voting total the securities "controlled" by the carrier or any person "controlling" the carrier. Cpon receiving refusals to assent, solicitors often purchased hold-out seeurities at abovemarket prices for the accounts of company directors. ${ }^{51}$ Again, the sale was made contingent upon the holder's prior assent to the $20 \mathrm{~b}$ plan;

49. E.g., "I want to make it clear that I would not have assented my 2700 shares of B \& II common stock except for the fact that it was hought from me abute market and I also want to make it clear that a condition of such sale was that I assent this studi befure signing." Affidavit of B\&MI-S, dated September 5, 1951, photustatic cupy un file in Yale Law Library (stock with market value of hetween $27 \%$ and $3: 4$ suld for 4 ).

50. As an example of solicitor loss transactions, see Depusition of Richard S. Xye (a paid solicitor), p. 77, dated October 19, 1951. rihutostitic cony an file in Yale Law Library, in which the admission is made that stosk was bought and suld on the same day on the stodk exchange at a loss- "the major purpose" of the transaction bsing to assent the stock.

51. See, e.g., Deposition of B\&M-7, pp. 25-9, 37-\$, dated Nuvemizer \&, 1951, Thatostatic copy on file in Yale Law Library: Deposition of ES:11-11, pp. 32-47, dated Oetubar 17, 1951, photostatic copy on file in Yale Law Library; Affilavit of B\&M-12, dated November 2, 1951, photostatic copy on file in Yale Law Library.

52. See, e.g., Deposition of BSMI-7, pp. 37-S, dated Nuvemher 8 , 1951, photostatic copy on file in Yale Law Library.

Whether director purchases actually violated 20b's "control" provisions, however, is uncertain. The ICC initially had stated that no shares were held by parsens in control of the carrier. Boston \& Maine R.R. Securities Modificatiun, 275 I.C.C. 397, 424 (19:0). But the subsequent purchase of additional shares during the sulicitation campaign might have placed directors in this category. In making its earlier finding that no Eustun \& Maine directors controlled the railrosd, the ICC-somewhat surprisingly-did not force the directors to reveal their holdings of $B \& M$ stcels Trial Brief of Defendant, The United States, pp. 28-9, Salis v. United States, 103 F. Supp. 392 (D.D.C. 1952). Th\& Commission's conduct is even more startling in view of interpretations given control language in other contexts. See, generally, Comment, 60 YALE L.J. 311 (1951). Official position creates no legal presumption of control, but "is a sort of red light." LQSS, SacoRtTies Regulation 467 (1951). ICC attitudes might be explained, huwever, by the iaet that the Commission has repeatedly urged elimination of the control provisiun from $20^{2}$. See, e.g., 65 ICC ANN. REP. 35 (1951). 
assents "controlled" by directors were recorded under the prior holder's name. A third technique employed the common borrowing transaction ordinarily utilized for the practice of short-selling on the stock exchanges. ${ }^{\text {t3 }}$ Solicitors, through a broker, borrowed stock held in the "street name" of another brokerage firm; upon payment of a transfer tax, the stock was listed in the name of the solicitor's broker, assented, and then returned:54 thus, in at least one instance, Boston \& Maine securities apparently were assented without the knowledge of a beneficial owner who happened to be strongly opposed to the plan. ${ }^{55}$ Such practices may only partially exhaust the store of passible manipulations. And barring intensive investigations, the ICC will ordinarily remain unaware of most of these methods : assents are received from "properly" listed security holders, while solicitor expense reports may easily conceal the relatively small costs incurred in both loss and borrowing transactions. ${ }^{50}$

Positive deterrents can be erected to check such practices. Solicitor dealings in the carrier's securities during the solicitation period should be forbidden. ${ }^{57}$

53. Borrowing permits the delivery of securities the seller does not yet own. Sec Shultz, The Securities Market 178-83 (5th ed. 1946).

54. Borrowing transactions were directed by Richard S. Nye, a partner in the firm of Georgeson \& $\mathrm{Co}$., which had been hired by the B \& M to solicit assents to its reorganization plan. Nye used his wife's name and her broker accounts in two major borrowing operations: 1) a loan in November, 1950, of 1300 shares of B \&'M common stock from the brokerage firm of Bache \& Co. in Philadelphia, which were then transferred to Shields \& Co. in New York, to Laidlaw \& Co., and finally to Montgomery, Scott \& Co.; and 2) a loan, in the closing days of the Boston \& Maine campaign period, of 2000 shares from Sartorius \& Co., transferred to Gude, Windmill \& Co., to Pyne, Kendall \& Hollister in New York. All stock involved in these transactions was held in brokers' street names, but owned by individual shareholders. Reports of the foregoing are found in Affidavit of Robert E. Bird, Cashier of Gude, Windmill \& Co., dated September 21, 1951, photostatic copy on file in Yale Law Library, and in Deposition of Richard S. Nyc, pp. 3, 17, 19-29, 35-42, 48, dated October 19, 1951, photostatic capy on file in Yale Law Library. Earlier, Nye had left standing orders with brokers to assent all B \& $M$ stock that came into his wife's accounts. Deposition of Richard S. Nye, pp. 17, 37, 43-4, 74-5, dated October 19, 1951, photostatic copy on file in Yale Law Library. The depositary thus received and counted assents for 1300 shares held by Montgomery, Scott \& Co. on December 1, 1950, Deposition of John Coulson (depositary employee), p. 49, dated October 16, 1951, photostatic copy on file in Yale Law Library, and for 2000 shares held by Pyne, Kendall \& Hollister, on December 14, 1950, the last day of the submission periad. Sce Deposition of Elizabeth Walker (depositary employee), p. 23, dated October 18, 1951, photostatic copy on file in Yale Law Library.

55. 1000 of the 1300 shares borrowed from Bache \& Co. and then assented were owned by Charles I. Podgor, a member of the Sakis committee. Affidavit of Charles I. Podgor, dated December 6, 1951, photostatic copy on file in Yale Law Library.

56. The federal borrowing tax amounts to 5 cents per $\$ 100$ of par or face value of the stocks and bonds borrowed, or 5 cents for each no par share. No tax is imposed on the return of bonds, nor are there any state taxes on the borrowing and return of either stocks or bonds. See SHuLTz, op. cit. supra note 53, at 226.

57. A similar prohibition, Rule U-62(g) (2), is already part of the SEC rules for solicitations under the Public Utility Holding Company Act of 1935. 17 CodE FEv. Recs. $\S 250.62(\mathrm{~g})(2)(1949)$. 
Criminal sanctions by Congress might prove a helpful deterrent to violations. And to forestall director purchases made contingent on prior assent, where the director has or thereby acquires a "controlling" interest in the carrier, the ICC should require full disclosure of director purchases, the manner of purchase (on the open market or from individual holders), and prices paid.:3 This information would facilitate investigation of possible malpractices.

\section{Inspection of Executed Assents}

The ICC delegates the actual recording of assents to "independent depositaries"-usually trust companies recommended by applicant carriers-to which security holders mail their approval of the proposed modification. ${ }^{5}$ Notice of acquisition of the requisite votes is relayed to the Commission through the affidavits of the railroad and depositary presidents; $; 0$ the ICC itself has never inspected assents. When opponents of the Boston \& Maine plan asked to examine these votes in open hearings, their request was denied. The Commission based its refusal upon a fear of "unjustified" delay since the opposition group was unable to support its motion with specific allegations of irregularities in the assent count. ${ }^{61}$ However, the Commission did not explain how dissenters. unable to inspect assents, could ever gain the information needed for such charges.

The Sakis court nevertheless found no abuse of administrative discretion in the ICC's action because $20 \mathrm{~b}$ had no specific requirement for a hearing on recordation accuracy. ${ }^{62}$ And to rebut plaintiffs' contention that sections of the Administrative Procedure Act independently required such a hearing ${ }^{63}$ the court relied on the APA's exemption of "proceedings in which decisions rest solely on inspections, tests or elections" ${ }^{\text {"4t }}$ from the hearing provisions. ${ }^{\mathrm{cs}}$

58. The Securities Exchange Act's insider trading provisions require only that curporate directors file periodic reports of a change in their holdings. The price of recent purchases and the method of purchase need not be shown. Seo Loss, Secunitres RrguLATTON 562-3 (1951).

59. See, e.g., Macon, Dublin \& Savannah R.R. Bond Modification, 271 I.C.C. 376, 388 (1948) (to be mailed to Mercantile Trust Co. of Baltimore, Md.); Central R.R. of N.J. Securities Modification, 271 I.C.C. 501, 529 (1949) (to be mailed to "such person, firm, or corporation, satisfactory to us, as may be selected by the applicant.")

60. See, e.g., Montana, Wyoming \& Southern R.R. Securities Modification, 271 I.C.C. 779,794 (1949): "[T]he applicant, within a reasonable time after the closing of the submission period, shall submit to us in connection with a supplemental application, a certificate as to the principal amount of affected bonds whose holders have assented to the plan as amended and the percentage thereof to the total principal amount outstanding. Such certificate shall be supported by a like certification by the Empire Trust Company [the depositary] which shall also be submitted to us."

61. Boston \& Miaine R.R. Securities MIodification, 275 I.C.C. 752, 756 (1951).

62. Sakis v. United States, 103 F. Supp. 292, 309 (D.D.C. 1952).

63. 60 SтAT. 237 (1946), 5 U.S.C. $\$ \$ 1001$ et seq. (Supp. 1950).

64. 60 Stat. 239 (1946), 5 U.S.C $\$ 1004$ (3) (Supp. 1950).

65. Sakis v. United States, 103 F. Supp. 292, 309 (D.D.C. 1952). 
Though literally covered by this exemption, its application to assent recording under $20 \mathrm{~b}$ could have been avoided. No legislative history clarifies the exception, but a fairly obvious interpretation would limit it to proceedings directed by the administrative agency itself. To rely upon the naked afficlavits of private parties is to make the questionable assumption that the APA's confidence in the impartiality, care, and skill of a public regulatory body extends to the functions of a profit-seeking trust company, paid by an interested $20 \mathrm{~b}$ participant. ${ }^{66}$

Apart from the legal issue, however, the possibility of undetected multiple assents on a single security, as well as unauthorized assents by purported agents, would suggest a needed revision of Commission attitudes. Under the conditions of large-scale stock market trading, a considerable percentage of stock and bond certificates, instead of being delivered to their purchasers, are held by brokers and listed in a broker's "street name." 37 When assents were received for less than the total amount of a broker's "street name" shares, the Boston \& Maine's depositary did not compel the broker to submit the certificate numbers of the assented shares. ${ }^{68}$ Resold, the same shares might have been assented again, since the carrier and depositary themselves had decided that a later transferee of a portion of the "street name" holdings would be presumed to have purchased unassented shares. ${ }^{00}$ Moreover, many assents were signed by brokers, attorneys, and the like who claimed to act on the authorization of the beneficial owner. The depositary apparently made no effort to spot check the purported authorizations ${ }^{70}$-an understandable omis -

66. See note 71 infra.

67. In 1937, 10 percent of the stock of all American corporations, and 20 percent of the stock beneficially owned by individuals, was reported under the "street names" of brokerage firms. See Investigation of Concentration of Economic Ponter (Monog. No. 29) in TNEC, Distribution of Ownership in the 200 Largest Nonfinancial Cokporations 9 (1940). See also Kmmet, Share Ownership in the United States 5562 (1952).

68. Deposition of Cecil Covert, pp. 28-34, dated October 18, 1951, photostatic copy on file in Yale Law Library.

69. Deposition of Raymond A. McIntire, pp. 105-12, dated October 17, 1951, photostatic copy on file in Yale Law Library.

70. Deposition of John Coulson, pp. 32-37, 113-14, 117, 142, dated October 16, 1951; Deposition of Raymond A. McIntire, pp. 27, 77, dated October 17, 1951, photostatic copies on file in Yale Law Library. In failing to require proof of authorization, the depositary disregarded a printed provision on ICC-approved assent forms, stating: "Note: In all cases in which the Letter of Assent is executed by an officer of a corporation, administrator, executor, trustee, guardian, agent, attorney or others acting in a fiduciary or representative capacity, proper evidence of authority to act in such capacity must be furnished." LeTTER of ASSENT FOR Stock holdERS, photostatic copy on file in Yale Law Library. A depositary official testified that, though the requirement was on the face of the assent, "the matter had been cleared up with the Railroad," which had advised non" observance. Deposition of John Coulson, p. 6, dated October 18, 1951, photostatic corpy on file in Yale Law Library. 
sion in view of the business ties between the carrier and depositary, maling the depositary anxious to have the plan accepted.71

The ICC can maintain the integrity of the assent recording process. An accurate $20 \mathrm{~b}$ count could be guaranteed if assenting owners were required to mail original securities certificates to the depositary in exchange for documents of deposit ${ }^{2}$ - a precaution that has been used in railroad reorganizations under Section 77 of the Bankruptcy Act. ${ }^{73}$ Perhaps less drastic than surrender of certificates would be assurance of open and continuous access to depositary records for all investor groups. Such access would permit dissenters to determine the extent of perhaps widespread double voting and to check on the validity of authorizations by beneficial owners.

\section{Reimbursement of Opposition Exponses}

Soon after 20b's enactment, the Commission interpreted the absence of a reimbursement clause in the statute as a positive prohibition, holding that it lacked the power to require corporate payment for the expenses of opposition committees. ${ }^{74}$ Sakis later sustained this position as a reasonable exercise of administrative discretion. ${ }^{75}$ Consequently, while management proponents of a $20 \mathrm{~b}$ plan may utilize company funds to finance mass solicitation efforts, ${ }^{\text {ic }}$

71. That the ICC has been somewhat lax in its choice of "independent" denositarics is suggested by the fact that $T$. Jefferson Coolidge, member of the executive committee of the Boston \& Maine's beard of directors, is also a director of the Old Colsny Trust Company, the independent depositary. Poon's Regrster of Drnectors amo Exexctrves 161. 947 (1953). Both Coolidge and Edward S. French. President of the Buston \& Maine. are directors of the First National Bank of Eoston, which avns the Old Culony Trust Company. Id. at 461 . The Old Colony is also the read's transfer agent, as are most depositaries in $20 \mathrm{~b}$ proceedings. Yet in denying the dissenters an oppirtunity to inspect assents, the Commission said: "The designation and appointment of a depusitary vas made in order to insure that the receipt and computation of assents would be carricd out hy a responsible and independent agency. . . Boston \& Maine R.R. Securities Modifieativn. 275 I.C.C. 752,755 (1951).

72. That Congress may have intended that documents of deposit would be used in $20 \mathrm{~b}$ campaigns is suggested by the statutory provision, Sectivn $200 \mathrm{~b}(11)$, esempting such certificates from Securities Act regulation.

73. Interviews with ICC official and members of the ICC Ear (Summer, 1952).

74. See note 21 supra.

75. Sakis v. United States, 103 F. Supp. 292, 313 (D.D.C. 1952).

76. The ICC has said that it is "unable to surply ... information concerning the total expenses incurred by the several carriers in suliciting assents to the approved madification plans." Communication to the Yale Law Jocmanc from C. E. Boles, Dircetur, Bureau of Finance, Interstate Commerce Commission, dated February 20, 1953, on file in Yale Law Library. The statement does not indicate clearly whether it is Commission policy to withhold such information, or whether the ICC has simply neglceted to require such data from successful $20 \mathrm{~b}$ applicants. Commission npinions, of cuurse, have carried railroad estimates of projected expenses, including a fairly definitive repurt by the Buston \& Maine that it foresaw the need to spend $\$ 56,780.86$ in bringing ahiut a completcd modification. Boston \& Maine R.R. Securities Modification, 275 I.C.C. 752, 757 (1951). E:penses in other $20 \mathrm{~b}$ campaigns-particularly the Lehigh Valley proceding-are rumured 
opposing groups must themselves defray the costs both of arguing before the Commission and soliciting opposition to management's drive for assents.

While apparently immune from judicial attack, the ICC's stand is neither warranted by congressional intent nor a wise policy for administering 20b's consent provisions. Though Congress took adverse note of the excessive "protective committee" expenses that so often accompanied traditional forms of bankruptcy reorganization, ${ }^{77} 20 \mathrm{~b}$ 's legislative history implies no clenr purpose to abolish payment of these fees altogether. ${ }^{78}$ On the contrary, ICC power to alter all "terms and conditions" of a submitted plan ${ }^{70}$ seems to establish full ICC discretion over this, as well as other features of $20 \mathrm{~b}$ campaigns. Policy a wise, the failure to provide for repayment of legal, printing, and mailing costs will almost certainly deter opposition groups from presenting their views to security holders. Unilateral use of corporate funds by management proponents thus might permit only favorable arguments to reach solicited owners; the resulting assents might then fail to reflect the informed judgment that alone permits the assent requirement to perform a truly protective function.

The ICC's refusal to reimburse is probably based upon a fear that the lure of legal fees and costs will draw officious and unnecessary parties into 20b proceedings. But such abuses are not inherent in reimbursement provisions; they may be regulated. Although the varying motives and interests of security holders would preclude forcing all opposition groups into a single committee

to have run much higher. Confidential Interview (Fall, 1952). It is the ICC's position that it has no power to approve or disapprove the expenditures of carriers in $20 \mathrm{~b}$ campaigns "unless perhaps unconscionable." Brief for the Interstate Commerce Commission, p. 39, Sakis v. United States, 103 F. Supp. 292 (D.D.C. 1952).

77. See Modification of Railroad Financial Structures, Sen. Rep. No. 1170, 79th Cong., 2d Sess. 55-58 (1946) ; Hearings before Special Subcammittec on Banlinuptcy and Reorganization of the Committee on the Judiciary on H.R. 3237, 80th Cong., 1st Sess. 73 (1947). Exorbitant legal fees and costs have always constituted a prime source of dissatisfaction with traditional forms of corporate reorganization. Classic critiques of these abuses are found in SEC, Report on the Study and Investigntion of tue WORK, ACtivities, Personner and Functions of Protective and Reorganization Commitrees pt. I, 161-242 (1937) ; Arnold, The Folklore of Capitalism 230, 252-9 (1937) ; LowenTHaL, THE INVESTOR PAYs 255-68 (1933).

78. On the one hand, the absence of a ban against reimbursement could be construed as indicating congressional approval for the payment of dissenters' costs. In vetoing a predecessor bill to $20 \mathrm{~b}$, President Harry S. Truman specifically castigated the vetoed measure for failing to bar the repayment of excessive fees and expenses, and asked that any new reorganization legislation contain "[a]ffirmative provisions to curb this evil. ..." See Memorandum of Disapproval, Hearings before Subcontmittec on Interstatc and Foreign Commerce on S. 249, 80th Cong., 1st Sess. 12 (1947). No reimbursement prohibition was enacted into $20 \mathrm{~b}$. On the other hand, a specific reimbursement section was placed in Chapter XV of the Bankruptcy Act in 1942, 56 STAT. 790-1 (1942), after expiration of the 1939 version of Chapter XV, which contained no such provision. 53 STAT. 1134 (1939). Thus, the legislative history of $20 \mathrm{~b}$ and its predecessors manifests no clear intent in either direction.

79. Section $20 \mathrm{~b}(3)$, quoted in note 15 supra. 
for purposes of argument before the Commission and solicitation campaigns, a reasonable compromise might require single representation in solicitation activities for holders of a particular class of securities. Similarly, the Commission could place ceilings on reimbursable expenses. And discretion can easily be retained to disallow reimbursement claims of parties who have entered a $20 \mathrm{~b}$ campaign for frivolous or harassing reasons.

\section{Conclusion}

Solicitation practices now possible under ICC rules render $20 \mathrm{~b}$ 's assent requirement a paper shield for the small investor's protection. But the choice of solicitation safeguards must be made with an eye toward their impact on the utility of $20 \mathrm{~b}$. Investor lethargy rather than opposition may cause a carrier's written communications to be ignored; inertia might deter investors from surrendering stock and bond certificates if surrender were required to signify assent. Thus an absolute ban against oral solicitation or a surrender requirement might preclude attainment of the requisite assents. However, other less drastic precautions might suffice to provide effective regulation of assent solicitation without emasculating whatever usefulness $20 \mathrm{~b}$ may possess. The ICC has a reservoir of discretionary power to implement these measures. And Congress should also act where criminal or civil sanctions appear necessary. 